Central Laboratory for Evaluation of Veterinary Biologics, Abbasia, Cairo.

\title{
STUDIES ON A RECENT IBD VIRUS FIELD VARIANT ISOLATE: (3) IMMUNOGENICITY OF THIS VARIANT STRAIN COMPARED WITH A CLASSICAL STRAIN IN BROILER CHICKENS
}

(With 2 Tables and 3 Figures)

By

\author{
S.A. NASSIF; ELHAM A. EL-EBIARY; \\ K.S. SHAABAN**; S.S. ABDEL-RAHMAN* \\ and M.M. AMER** \\ * Veterinary Serum and Vaccine Research Institute. \\ ** Faculty of Veterinary Medicine, Cairo University
}

(Received at 29/9/2005)

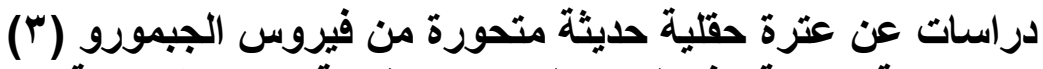
دراسة مناعية هذه العترة المتحورة مقارنة منة بعترة منئة كلاسيكية من فيروس الجمبورو في دجاج التسمين

سمبير عبل المعز ناصف ، إلهام عطا الإبيارى ، خالد شعبان

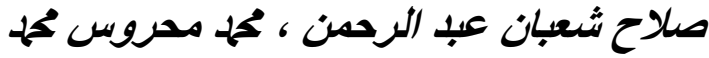

تم تحضير ثلاثة لقاحات زيتية مثبطة ضد مرض الجمبورو وذلك باستخدام عترتين من فيروس تئرس

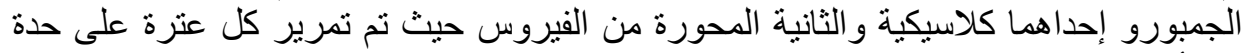

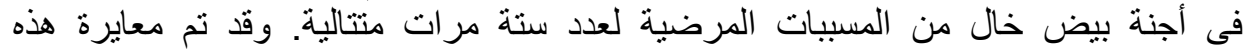

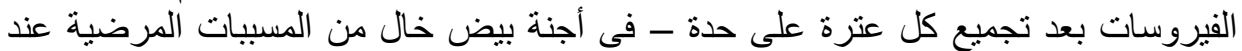

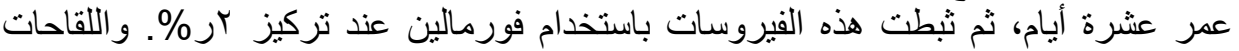

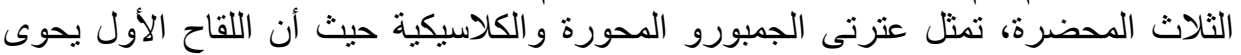

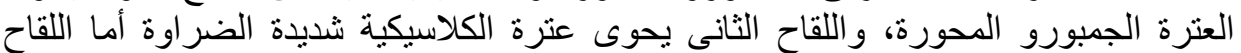

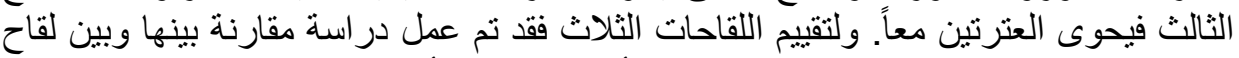

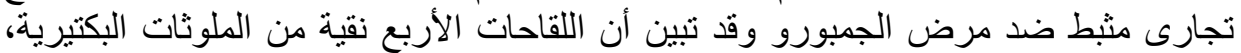

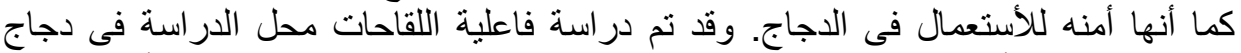

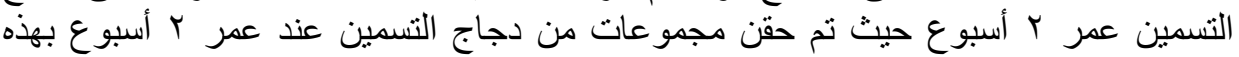

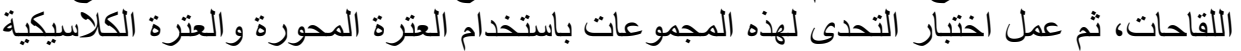

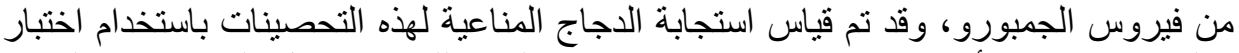

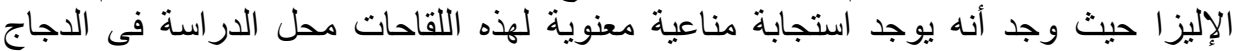

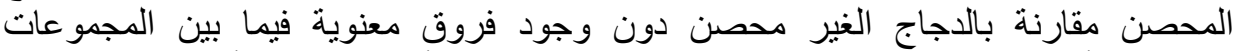
المحصنة بأى من هذه اللقاحات. وبالنسبة لاختبار التحدى فقد أكدت الدراسة أن اللقاح المحضر فئر النقات 
من العترة المحورة لفيروس الجمبورو بحمى الدجاج المحصن به ضد في فيروسات الجمبورو

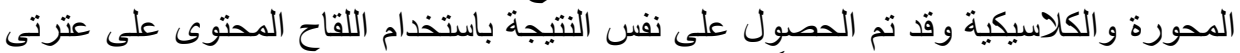

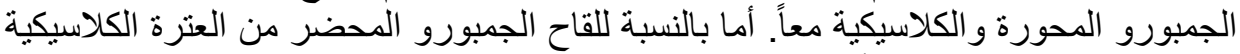

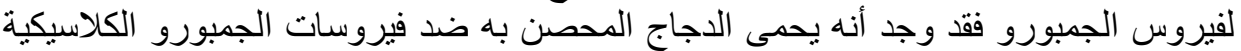
فقط وليس ضد العثر ات المحورة من الفيروس نفسها لفيه.

\section{SUMMARY}

Three inactivated water-in-oil-in-water-emulsion infectious bursal disease virus (IBDV) vaccines were prepared from the Del/E related IBDV variant strain and a classical vvIBDV strain. Each IBDV strain were propagated for 6 serial passages in specific pathogen free (SPF) embryonated chicken eggs (ECE). The harvested IBD viruses were titrated in 10 day old ECE and inactivated using formalin at a final concentration of $0.2 \%$ of the total volume. The fist vaccine contained $\mathrm{Del} / \mathrm{E}$ related IBDV variant strain, the second vaccine contained vvIBDV strain and the third vaccine contained both variant and vvIBDV strain. The 3 prepared IBDV vaccines are evaluated compared to a commercial inactivated IBDV vaccine, all the 4 vaccines proved to be sterile and safe. The efficacy of each vaccine was assisted by inoculation into a group of 14 day old broiler chicks via subcutaneous rout and challenged (2 weeks later) with Del/E related IBDV variant strain and the classical vvIBDV strain. The humeral immune response were determined using indirect ELISA, the geometric mean (GM) ELISA titer of the vaccinated chicken groups are significantly higher than the non vaccinated chickens, with no significant difference between the vaccinated chicken groups despite the variation in the IBDV strains. The protection was evaluated at 5 and 10 days post challenge, based on gross and microscopic lesions, bursal indices, proventricular/body weight ratio and bursl lesions scores. Vaccines made of variant IBDV alone or combined with vvIBDV protected chickens challenged with either the classical vvIBDV or the Del/E related IBDV variant strain while vaccines made of the classical IBDV strain alone protected chickens challenged with the classical vvIBDV strain but not against the Del/E related IBDV variant strain.

Key words: Vaccination, IBD virus, broiler chickens. 


\section{INTRODUCTION}

Infections bursal disease virus (IBDV), a member of the birnavirus group is the etiological agent of a highly contagious immunosuppressive disease of young chickens (Saif., 1991). The bursa of fabricious (BF) is the target organ of infection by IBDV, (Lukert and Saif., 1991). Variant IBDV strains have been implicated as a cause of the transmissible viral proventiculitis (TVP) in brolier chickens (Bayyari et al., 1995; Huff et al., 2001; Newberry, 1996 and Amer and Nassif. 2005). In Egypt Del/E IBDV variant strains; as detected by an antigen capture ELISA Kit (Hussien et al., 2003) and RT/PCR- RFLP assay (Amer and Nassif 2005); was suspected to be the cause of TVP.

The economical impact of the TVP could be summarized in higher than average mortality, stunted growth, poor feed conversion rate and passage of the undigested feed in the feaces of the affected chickens (McNulty, 1991 and Goodwin, 1993).

Because vaccination is currently the most effective control measure of IBDV, there is continous need to develop efficacious vaccines for commercial poulty production.

The objective of the present study is to prepare a combined and single inactivated vaccines from the variant Del/E strains and a classical vvIBDV strain previously isolated by Nassif 2001. And evaluate it in comparison with a commercial inactivated IBDV vaccine.

\section{MATERIALS and METHODS}

\section{Embryonated chicken eggs (ECE)}

Specific pathogen free (SPF) ECE were obtained from Nile SPF eggs, Kom, Oshiem, Fayoum, Egypt, and used for the propagation and titration of IBDVs.

\section{Broiler chicks:}

Two hundred -one day old broiler chicks are obtained from El-wady company, reared in a good ventilation and clean pens, water and feed are supplied adlibidum.

\section{IBDVs:}

Two strains of IBDV, a classical vvIBDV and a variant Del /E IBDV, were used. The vvIBDV was previously isolated and identified by Nassif 2001 . The Del/E variant IBDV was detected and identified by Amer and Nassif 2005. 
Adaptation of IBDVs to ECE: (Hassan and Saif., 1996)

Each IBDV strain $(0.1 \mathrm{ml})$ was inoculated into a group of ECE (11 days old) via the chorioallantoic route. Eggs were incubated, observed daily and those with dead embryos during the first 24 hours post inoculation (PI) were discarded. On the third day, eggs containing dead embryos and those still surviving were chilled to $4^{\circ} \mathrm{C}$.

Embryos, and chorioallantoic membranes (CAMs) were harvested and examined for the presence of IBDV characteristic lesions. The CAMs and the embryonic viscera were washed, homogenized and suspended in phosphate buffered saline (PBS, pH 7.2) the suspension was freezed and thawed in 3 cycles then centrifuged and the supernate was filtered and inoculated into another batch of SPF embryos and six serial passages were completed in a similar manner.

\section{Titration of IBDVs in SPF embryos:}

The egg adapted vvIBDV and Del/E variant IBDV were titrated in 10-day-old SPF embryonated eggs. The virus titer was determined as the EID $_{50}$ (Lukert and Saif., 1991).

\section{Vaccine preparation:}

a-Virus inactivation: (Wyeth et al.,1981)

Each IBDV strain was inactivated using formalin in a final concentration of $0.2 \%$ of the total volume (virus - formalin mixture). The absence of residual infectivity of the inactivated virus was confirmed by inoculation into 10 day old ECE $(0.2 \mathrm{ml} / \mathrm{egg})$ via the allantoic sac. Three serial passages were completed in a similar manner, before the batch of the prepared vaccines were considered safe.

b-Preparation of water in-oil-in-water emulsion (w-o-w-e) IBDV vaccines: (Abdel-Wanees et al. 2004)

The double emulsion form of multiple emulsion (w-O-w-e) was prepared from a simple water in oil emulsion by re-dispersing it in an outer saline phase with aqueous phase emulsifier. Paraffin oil (white 300) white oil quality FDAIAL usp no 05200 Mobil, Aquous phase emulsifier (tween 80$)$ supplied by sigma of $(H L B=15)$ and oil phase emulsifier arlacil (Span 80, supplied by Micbil, Aleyandrid (HLB =4.3) were used. The hydrophile - lipophile - Balance (HLB) of the surfactant mixture of the perpared batches were 9.36 determined as described by Schick (1966).

The prepared w-o-w-e IBDV vaccines have the following physical features:- The aqueous to oil ratio of 2:1, aqueous phase emulsifier concentration is $3 \%$ and the oil phase emulsifier concentration 
is $10 \%$ of the oil phase and of viscosity of 1 second at $20^{\circ} \mathrm{C}$ for $0.4 \mathrm{ml}$ flow times.

\section{Evaluation of the prepared IBDV vaccines:- 1-Sterility test:}

The prepared vaccines were inoculated into nutrient agar, thioglycolate broth, PPLO media and sabaroaud's dextrose agar media to assure their freedom from any bacterial, mycomplasma or fungal contaminations

\section{2- Safety test:}

A group of 3 week old chicks were used for each vaccine. Each chick was inoculated with double field dose via $\mathrm{I} / \mathrm{M}$ route and the chicks, were observed for 2 weeks for any signs of local reactions, irritations or systemic reactions.

\section{3- Vaccines efficacy:}

Three IBDV vaccines were prepared:

Vaccine No.(1): contained the variant Del/E IBDV strain

Vaccine No.(2): contained the vvIBDV strain

Vaccine No.(3): contained both vvIBDV and variant Del/E strains

\section{Experimental designs:}

Efficacy of the 3 Prepared inactivated IBDV vaccines were examined compared with that of commercial inactivated IBDV vaccines (Newcevac, intervet company) as follow:

One hundred and fifty -14 day - old chicks were used -, the chicks were divided into 5 groups, each group contained 30 chicks which represent 3 subgroups ( $a, b$ and $c$ ) each of 10 chicks. The experimental groups were vaccinated subcutaneously at the mid-dorsal region of the neck with $0.5 \mathrm{ml}$ of the vaccine as follow:

Group 1: received vaccine No.(1) (at least $10^{5.5} \mathrm{EID}_{50}$ per dose)

Group 2: received vaccine No.(2) (at least $10^{5.5} \mathrm{EID}_{50}$ per dose)

Group 3: received vaccine No.(3) (at least $10^{5} \mathrm{EID}_{50}$ of each strain per dose)

Group 4: received the commercial IBDV vaccine (at least $10^{6} \mathrm{EID}_{50}$ per dose)

Group 5: none vaccinated control.

Blood samples were collected just prevaccination against IBD, at $7^{\text {th }}$ day post vaccination (PV), $14^{\text {th }}$ day PV, $21^{\text {st }}$ day PV, $28^{\text {th }}$ day PV and every 4 weeks for 2 months for detection of the active immune response against IBD using indirect ELISA.

At the $14^{\text {th }}$ day PV the birds in subgroups "a" were challenged with $10^{4}$ EID $_{50}$ of the vvIBDV per bird, while birds in subgroups "b" 
were challenged with $10^{4} \mathrm{EID}_{50}$ of the Del/E variant strain of IBDV via occular and oral routes.

The challenged chickens were observed daily for any clinical sings and /or deaths.

At the $5^{\text {th }}$ and $10^{\text {th }}$ day post challenge (PC) five birds from subgroups "a" and "b" were euthanized then weighed, and necropsied. The BF and proventriculous of each bird also weighed and taken for histo pathological examination

The protection percentage $=100-\%$ of birds with bursal atrophy and bursal lesion score $>3$ (Nassif, 2001)

\section{Histopathology:}

Methods of preparations, examination and interpretation of the results were carried out according to Tainmura et al (1995)

\section{Enzyme Linked Immuno Sorbent Assay:}

ELISA kits supplied from Idexx laboratories Inc. were used and the methodology was conducted according to manufactural instructions Organ/Body weight (BW) ratio:- Tainmura et al (1995)

The BF and proventriculous of dead or euthanized birds are collected and weighed and the organ/BW ratio was determined as follow:

Organ weight (gm) X 1000

Total body weight (gm)

Bursal weight index: (Lucio and Hitchner, 1979)

Bursal weight index $=\frac{\mathrm{BF} / \mathrm{BW} \text { ratio of the challenged group }}{\mathrm{BF} / \mathrm{BW} \text { ratio of the non challenged group }}$

Chickens with bursal index lower than 0.7 were considered to have bursal atrophy.

\section{RESULTS}

\section{Adaptation of IBDVs to egg embryos:}

Embryos inoculated with vvIBDV and Del/E variant IBDV strains showed mortalities after 3 days in the first 3 passages only. Consequently the embryos were chilled after 72 hour PI in the subsequent passages. The CAMs of the dead embryos showed congestion and edema. The embryos showed subcutaneous 
haemorrhage, dwarfing, heart palness, splenomegally and necrosis of liver and spleen.

\section{Titres of the IBDVs:}

The titre of vvIBDV and the Del/E related IBDV variant strain was $10^{6} \mathrm{ElD}_{50} / \mathrm{ml}$ before inactivation.

\section{Evaluation of the prepared IBDV vaccines: Sterility test:}

The results of sterility test revealed that the prepared vaccines are free from aerobic and anaerobic bacteria, mycoplasma and fungal contaminants.

\section{Safety test:}

No deaths, nor abscesses or any local reactions were observed in the inoculated chickens along the experimentation period that is means that the examined vaccines are safe.

\section{Potency test:}

The results of the experiment using the Del/E related IBDV inactivated vaccine vac. No. (1), vvIBDV inactivated vaccine vac. No. (2). And the combined in activated vaccines vac No. (3) are summerized in Tables 1, 2 and Figures 1, 2 and 3. The humoral immune response of the experimental chickens to vaccine No. 1 as measured by indirect ELISA (Table 1 and Fig.1) showed a significant $(\mathrm{P}<0.05)$ increases in GM ELISA titres in all vaccinated groups compared to the non vaccinated control group, from the $2^{\text {nd }}$ week PV and continued to reach the peak at the $4^{\text {th }}$ week PV then declined very slowly from the $5^{\text {th }}$ week till the end of the experiment. Data in Table (1) showed that there is no significant difference in GM ELISA antibody titre between the vaccinated groups all over the experimentation period.

The results of challenge are summerized in Table (2), Figures 2 and 3 that showed that the chicken group that received vaccine No. 1 have $100 \%$ protection when challenged with either Del/E related IBDV strain or vvIBDV strain as indicated by the results of bursal indics (no bursal atrophy) and proventricular /BW (Not higher than that of non challenged control) and histopathological score lesions of bursae and the histopathology of proventriculus. The same results are obtained for the chicken group received the combined IBDV vaccine vac. No. (3). On the other hand the chicken group, received vaccine No. (2) and that received vac. No. (4) showed $100 \%$ protection against challenge with the vvIBDV, while $70 \%$ and $60 \%$ protection were obtained respectively against the Del/E related IBDV starin, as indicated by bursal atrophy 
bursal lesion score of 4 and significantly higher proventricular/BW ratio compared to the non challenged control.

In the control group the protection percentages were $30 \%$ for both vvIBDV strain and Del/E related IBDV variant strain, as indicated by bursal and proventricular indices and their histopathological findings at $5^{\text {th }} \& 10^{\text {th }}$ days PC. Fig. 2 showed the histopathological finding of the bursa of non vaccinated and challenged chickens with Del/E related IBDV variant strain which represented as sever lymphocytic depletion and inter-follicular oedema, the histopathological score lesion is 4 . Fig (3) showed the histopathological finding of the proventriculous in non vaccinated and challenged chickens with Del/E related IBDV variant strain which represented as sever epithelial hyperplasia of the mucosa with inflammatory cells infiltration with cellular damage in the glandular lumen and hyperplasia of the glandular alveoli.

Table 1: Humoral immune response of the experimental broiler chickens to the 3 prepared inactivated IBDV vaccines in comparison with a commercial inactivated IBDV vaccine as measured by indirect ELISA.

\begin{tabular}{|c|c|c|c|c|c|c|c|}
\hline \multirow{3}{*}{ Vaccine } & \multicolumn{7}{|c|}{ GM ELISA titre } \\
\hline & \multirow{2}{*}{$\begin{array}{c}\text { Pre } \\
\text { vaccination }\end{array}$} & \multicolumn{6}{|c|}{ Post vaccination } \\
\hline & & $2^{\text {nd }} W$ & $3^{\text {rd }} \mathrm{W}$ & $4^{\text {th }} \mathrm{W}$ & $8^{\text {th }}$ & $12^{\text {th }}$ & $16^{\text {th }}$ \\
\hline Vac No. 1 & 1800 & 1530 & 2250 & 4100 & 3100 & 2500 & 2000 \\
\hline Vac No. 2 & 1800 & 1580 & 2800 & 4450 & 3350 & 2700 & 2100 \\
\hline Vac No. 3 & 1800 & 1600 & 2750 & 4150 & 3200 & 2500 & 2050 \\
\hline Vac No. 4 & 1800 & 1650 & 2810 & 4210 & 3300 & 2800 & 2000 \\
\hline $\begin{array}{c}\text { Non vac. } \\
\text { Control }\end{array}$ & 1800 & 912 & $840 *$ & $650 *$ & $515^{*}$ & $540 *$ & $460 *$ \\
\hline
\end{tabular}


Table 2: Evaluation of the protection percentage of the 3 prepared IBDV vaccines in comparison with a commercial IBDV vaccine.

\begin{tabular}{|c|c|c|c|c|c|c|c|c|c|}
\hline \multirow[t]{2}{*}{ Vaccine } & \multirow{2}{*}{$\begin{array}{c}\text { Challenge } \\
\text { virus }\end{array}$} & \multicolumn{2}{|c|}{$\begin{array}{c}\text { Bursal index at } \\
\text { days post } \\
\text { challenge }\end{array}$} & \multicolumn{2}{|c|}{$\begin{array}{c}\text { Bursal lesion } \\
\text { scores at days } \\
\text { post } \\
\text { challenge }\end{array}$} & \multicolumn{2}{|c|}{$\begin{array}{l}\text { Proventricular / } \\
\text { BW ratio at days } \\
\text { post challenge }\end{array}$} & \multirow{2}{*}{ 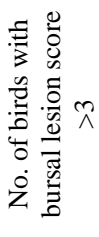 } & \multirow{2}{*}{ 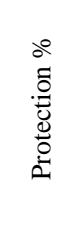 } \\
\hline & & 5 & 10 & 5 & 10 & 5 & 10 & & \\
\hline \multirow{2}{*}{$\begin{array}{l}\text { Vac. } \\
\text { No. } 1\end{array}$} & $\begin{array}{l}\text { Variant } \\
\text { IBDV }\end{array}$ & 1.00 & 0.964 & 1.0 & 1.5 & $\begin{array}{c}0.820 \pm \\
0.003\end{array}$ & $\begin{array}{c}0.781 \pm \\
0.02\end{array}$ & $0 / 10$ & $100 \%$ \\
\hline & VvIBDV & 0.992 & 0.947 & 1.0 & 1.2 & $\begin{array}{c}0.801 \pm \\
0.009\end{array}$ & $\begin{array}{c}0.790 \pm \\
0.005\end{array}$ & $0 / 10$ & $100 \%$ \\
\hline \multirow{2}{*}{$\begin{array}{l}\text { Vac. } \\
\text { No. } 2\end{array}$} & $\begin{array}{l}\text { Variant } \\
\text { IBDV }\end{array}$ & 0.615 & 0.437 & 2.8 & 3 & $\begin{array}{l}1.5 \pm \\
0.11\end{array}$ & $\begin{array}{c}1.71 \pm \\
0.20\end{array}$ & $3 / 10$ & $70 \%$ \\
\hline & VvIBDV & 0.997 & 0.988 & 1.0 & 1.2 & $\begin{array}{c}0.800 \pm \\
0.05\end{array}$ & $\begin{array}{c}0.740 \pm \\
0.08\end{array}$ & $0 / 10$ & $100 \%$ \\
\hline \multirow{2}{*}{$\begin{array}{l}\text { Vac. } \\
\text { No. } 3\end{array}$} & $\begin{array}{l}\text { Variant } \\
\text { IBDV }\end{array}$ & 0.999 & 0.979 & 1.0 & 1.2 & $\begin{array}{c}0.850 \pm \\
0.003\end{array}$ & $\begin{array}{c}0.785 \pm \\
0.009\end{array}$ & $0 / 10$ & $100 \%$ \\
\hline & vvIBDV & 1.00 & 0.965 & 1.0 & 1.5 & $\begin{array}{c}0.845 \pm \\
0.008\end{array}$ & $\begin{array}{c}0.800 \pm \\
0.008\end{array}$ & $0 / 10$ & $100 \%$ \\
\hline \multirow{2}{*}{$\begin{array}{l}\text { Vac. } \\
\text { No. } 4\end{array}$} & $\begin{array}{l}\text { Variant } \\
\text { IBDV }\end{array}$ & 0.611 & 0.420 & 3 & 3 & $\begin{array}{c}1.9 \pm \\
0.3\end{array}$ & $\begin{array}{c}1.95 \pm \\
0.4\end{array}$ & $4 / 10$ & $60 \%$ \\
\hline & vvIBDV & 0.915 & 0.899 & 1 & 1.2 & $\begin{array}{c}0.811 \pm \\
0.003\end{array}$ & $\begin{array}{c}0.800 \pm \\
0.009\end{array}$ & $0 / 10$ & $100 \%$ \\
\hline \multirow{2}{*}{$\begin{array}{c}\text { Non vac. } \\
\text { A,b }\end{array}$} & $\begin{array}{l}\text { Variant } \\
\text { IBDV }\end{array}$ & 0.451 & 0.308 & 4 & 4 & $\begin{array}{l}2.0 \pm \\
0.325\end{array}$ & $\begin{array}{l}2.11 \pm \\
0.420\end{array}$ & $7 / 10$ & $30 \%$ \\
\hline & vvIBDV & 0.514 & 0.361 & 4 & 4 & $\begin{array}{c}0.800 \pm \\
0.005\end{array}$ & $\begin{array}{c}0.750 \pm \\
0.009\end{array}$ & $7 / 10$ & $30 \%$ \\
\hline $\begin{array}{c}\text { Non vac. } \\
\text { c }\end{array}$ & & ND & ND & 0 & 0 & $\begin{array}{c}0.850 \pm \\
0.09\end{array}$ & $\begin{array}{c}0.860 \pm \\
0.07\end{array}$ & - & - \\
\hline
\end{tabular}

ND: Not Done 
Assiut Vet. Med. J. Vol. 51 No. 107 October 2005 


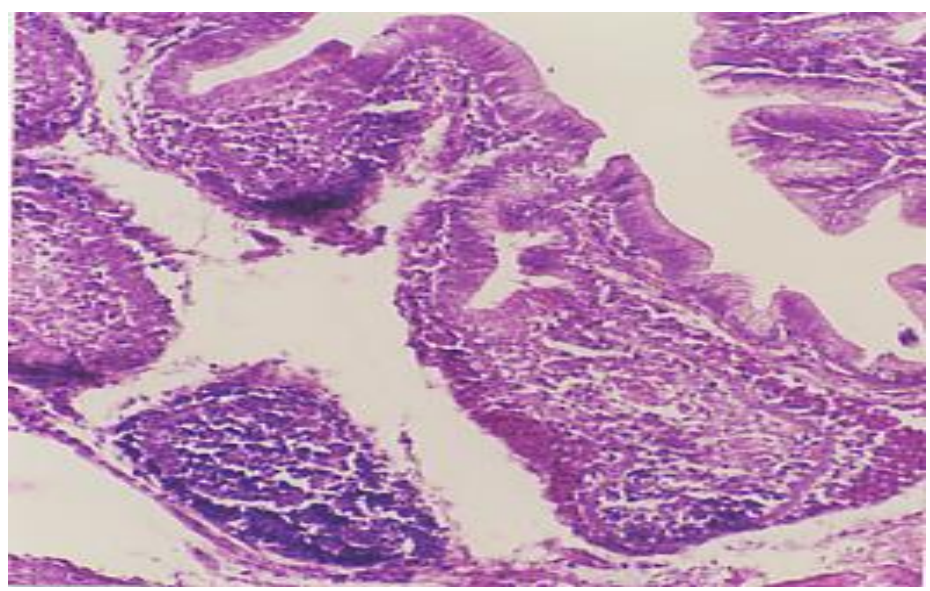

Fig. 2: BF of the non-vaccinated broiler chickens that challenged with the Del/E related IBDV variant strain at $5^{\text {th }}$ day post challenge showing interfollicular oedema, lymphocytic depletion and esinophils aggregation in the follicular cortical portion ( $\mathrm{H} \& \mathrm{E}, 40 \mathrm{x})$.

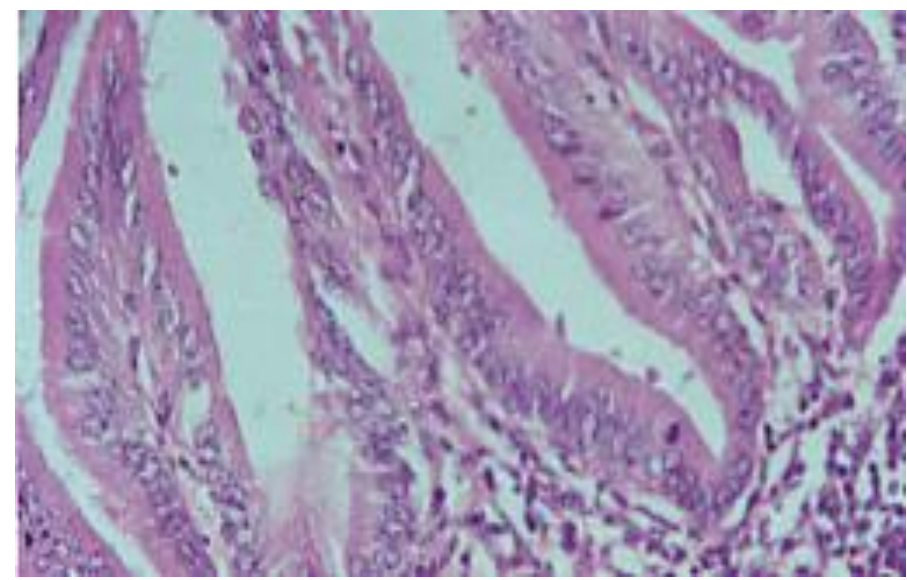

Fig. 3: Proventriculus of non-vaccinated broiler chickens that challenged with the Del/E related IBDV variant strain at $5^{\text {th }}$ day post challenge showing severe epithelial hyperplasia of the mucosa with inflammatory cells infiltration with cellular damage in the glandular lumen and hyperplasia of the glandular alveoli (H \& E, 40x). 


\section{DISCUSSION}

Our study was conducted in 3 steps, the first step was detection, isolation and identification of a new variant IBDV strain using RT/PCRRFLP assay, that contributed to be the cause of TVP in broiler chickens. The results confirm that the isolated IBDV is a variant strain related to the Del/E variant IBDV. In the second stage we study the pathogenicity and immune suppressive potential of this variant strain and in the present study we try to complete the previous work by preparation of inactivated w-o-w-e IBDV vaccine from our Del/E related IBDV strain in a trial to overcome, face and even prevent the spread of TVP in broiler chickens in Egypt.

In the present study 3 inactivated IBDV vaccines were prepared; vaccine No. (1) contained the Del/E related strain; vaccine No.(2) contained the vvIBDV and vaccine No. (3) contained both IBDV stains. To evaluate the efficacy of the prepared vaccines a commercial inactivated IBDV vaccine was used. The humoral immune response of the experimental chickens, as detected by indirect ELISA, showed significant increase in GM ELISA antibody titre in all vaccinated Groups, compared with non vaccinated Control group, along the experimentation period from the second week PV (Table 1). Our results agreed with that obtained by Amal et al., 2002.

No significant differences were detected between the levels of GM antibody ELISA titre of the vaccinated chicken groups.

We could explain this result by the similarity of IBDV titers, before inactivation, in the 4 vaccines despite the variation in the IBDV strains contained in these vaccines. The 2 IBDVs either the classical or the variant strains are related to serotype 1 of IBDV, so they shared a group of common epitopes which contribute common antigen. So the obtained result are logic.

The results of challenge test (Table 2) revealed that the chicken groups received vaccine made of variant Del/E IBDV strain either vaccine No. 1 or vaccine No. 3, have $100 \%$ protection against challenge with either Del/E related variant IBDV strain or vv IBDV strain as detected by bursal indices proventricular/B.W ratio and histopathological lesion score of $\mathrm{BF}$ and proventriculus. While the chicken groups received vaccine made of classical IBDV strain have $70 \%$ and $60 \%$ protection against challenge with Del/E related variant IBDV strains and $100 \%$ protection against challenge with vvIBDV strain. 
Our results, agreed with that obtained by Saif, 1994; Nassif 2001 and Ismail and Saif 1994 who found that inactivated IBDV vaccine made of variant IBDV protected chickens against challenge with either standard or variant viruses even at high doses, while inactivated IBDV vaccine made of the standard strains protected chicken against challenge with the standard strains at high or lows doses and only against the low challenge dose of variant strain but not against the high dose.

It was concluded that the addition of the Del/E related IBDV vaccine to all the vaccine preparation containing inactivated IBDV (either univalent Gumboro, or $\mathrm{ND}+\mathrm{G}, \mathrm{ND}+\mathrm{G}+1 \mathrm{~B}$ or $\mathrm{ND}+\mathrm{G}+\mathrm{IB}+\mathrm{Reo}$ that applied to breeders will be helpful in protection of progeny against both IBD and TVP. Also continuous and regular surveys on the IBD outbreaks in Egypt is necessary to isolate and identity the new strains of the IBDV, that could be circulate in the field, to be always ready and standby for continuous prevention and control of the IBD in Egypt.

\section{REFERENCES}

Abdel-Wanees, N.A, Abdel Rahman, S.S., Salwa El Asily and Daoud, A.U. (2004): New Approach in the methodology of inactivated Newcastle disease oil emulsion vaccine preparation. The proc. of $6^{\text {th }}$ Scientific Conference of the Egyptian Veterinary Poultry Assoc.

Amal, I. Abdel-Hady, Elham, A. El-Ebiary and Fekria. A. El-Bourdiny (2002): Comparison between two different inactivators in preparation of inactivated infectious bursa disease vaccine using ISA-70 oil adjuvant. The Proceeding of the $7^{\text {th }}$ Annual Conference of the Egyptian Journal of Immunology, page: 6977.

Amer, M.M. and Nassif, S.A. (2005): studies on recent IBD virus field variant isolates: 1- Genomic identification and differentiation using RT/PCR-RFLP. The Proc. Of the $4^{\text {th }}$ Sci. Conf., Fac. Vet. Med., Beni-Suef Univ.

Bayyari, G.R.; Huff, W.E.; Baolg, J.M.; Rath, N.C. and Beasley, J.W. (1995): Experimental reproduction of proventriculitis using homogenates of proventricular tissue. Poult. Sci. 74: 17991809. 
Goodwin, M.A. (1993): Runting, stunting, enteritis and failure to thrive. AAAP Symposium on newly emerging and RE-emerging avian diseases: Applied Research and Practical Application for Diagnosis and Control, program of the $130^{\text {th }}$ Annual Meeting of the American Association of Avian Pathologists, Minneapolis, MN.P. 145 (Abstract); Symposium Proceedings July 18, pp. 1829.

Hassan, M.K. and Saif, Y.M. (1996): Influence of the Host system on the pathogenicity, immunogenicity and antigenicity of infectious bursal disease virus. Avian Dis. 40: 55-561.

Huff, G.R.; Zheng, Q.; Newberry, L.A.; Huff, W.E.; Baleg, J.M.; Rath, N.C.; kim, K.S.; Martin, E.M.; Goeke, S.C. and Skeels, J.K. (2001): Viral and bacterial agents associated with experimental transmission of infectious proventriculitis of broiler chickens. Avian Dis., 45: 828-843.

Hussein, H.A.; Aly, A.M.; Sultan, H. and Al-Safty, M. (2003): Transmissible viral proventriculitis and stunting syndrom in broiler chickens in Egytp: 1. Isolation and characterization of variant infectious bursal disease virus (IBDV). Vet. Med. J., Giza, 51 (3): 455-462.

Ismail, N.M., and Y. M. Saif (1991): Immunogenicity of infectious bursal disease viruses in chickens. Avian Dis. 35: 460-469.

Lucio, B. and Hitchner, S.B. (1979): Infectious bursal disease emulsified vaccine: Effect upon neutralizing antibody levels in the dam and subsequent protection of the progeny. Avian Dis., 23 (2): 466-478.

Lukert, P.D. and Saif, Y.M. (1991): Infectious bursal disease. In: Diseases of poultry, $9^{\text {th }}$ ed. B. W. Calnek H. J. Barnes, C.W. Beard, W.M. Reid, and H.W. Yolder, Jr., eds. Iowa State University Press, Ames. Iowa. Pp. 648-663.

McNulty, M.S. (1991): Runting stunting syndrome in broiler chickens. Proceed. Poult. Hlth. Condem., Ocean City, Maryland, pp. 115124.

Nassif, S.A. (2001): A trial for preparation and evaluation of a local live infectious bursal disease virus vaccine. Ph.D. thesis, Fac. Vet. Med., Cairo Univ.

Newberry, L.A. (1996): Determination of the role of standard and variant strains of infectious bursal disease virus in induction of viral proventriculitis in chickens. Ph.D. Dissertation Univ. of Arkansas, Fagelteville, AR. 
Saif, Y.M. (1991): Immunosuppression induced by infectious bursal disease virus. Vet. Immunol. Immunopathol. 30:45-50.

Saif, Y.M. (1994): Antigenicity and immunogenicity of infectious bursal disease virus" Int. Symp. On infectious bursal diseases and chicken infectious anaemia, Rauischholzhauson, Germany. 2124 June, 37-39.

Schick, M.J. Nouionic surfactants (1966): Marchel Dekker, Inc. New York. PP 609-611.

Tainmura, N.; Tsukamoto, K; Nakamura, K.; Narita, M. and Maeda, M. (1995): Association between pathogenicity of infectious bursal disease virus and viral antigen distribution detected by immunohistochemistry Avian Dis., 39: 9-20.

Wyeth, P.J.; Cough, R.E. and Cullen. G.A. (1981): Immune response of breeding chickens to trivalent oil emulsion vaccines; response to Newcastle disease and infectious bursal disease. Cent. Vet. Lab. New Haw, weybridge, Surrey, UK. Vet. Rec., 108 (4): $72-$ 75 . 
Assiut Vet. Med. J. Vol. 51 No. 107 October 2005 